\title{
Social Justice Collaboration in Schools: A Model for Working with Undocumented Latino Students
}

\author{
Cassandra A. Storlie \\ The University of Iowa \\ Elizabeth A. Jach \\ Cornell College
}

\begin{abstract}
Undocumented Latino students raise unique challenges for school counselors and student affairs professionals. Fears of deportation, limited access to higher education, and restrictions in future opportunities for employment are common. These obstacles can be lessened in the academic setting when school counselors and student affairs professionals work collaboratively toward systemic social justice advocacy. The purpose of this article is to illuminate the challenges encountered by undocumented Latino students and to introduce an ecological model that promotes social action within a $K-16$ system. Reflections on individual and collaborative social action interventions for undocumented students will be included. Implementation of this model may generate insights into how to educate professionals in both school counseling and student affairs on realistic and empowering methods to facilitate opportunities for undocumented Latino students.
\end{abstract}

Keywords. social justice, undocumented students, collaborative efforts, $\mathrm{K}-16$ 


\section{Introduction}

"I wish I would have known ahead of time that things weren't going to be the same for me. I hated comparing myself to friends and family who had papers and seeing the opportunities they had. I wanted to go to college but no one at school ever talked to me about it - or how I could make it possible. I was accepted to three colleges but there was no way my family and I could pay out of pocket (personal communication, August 7, 2011)".

There are currently 38 million immigrants in the United States (U.S.) and of those approximately 12 million are undocumented (Gonzales, 2009). According to Oliverez, Chavez, Soriano, and Tierney (2006), "An undocumented person is a non-citizen who entered the United States without legal immigration status or who stayed after the period he/she was authorized to be here" (p. 6). Many undocumented students, known as the "1.5 generation," entered this country at a young age, having no choice but to follow their caretakers' direction in crossing into the U.S. According to Gonzales (2009): "[Undocumented students] are not first-generation immigrants because they did not choose to migrate, but neither do they belong to the second generation because they were born and spent part of their childhood outside of the U.S. In a sense, they straddle two worlds (p. 7)." As these students assimilate, they recognize how their lack of documentation translates into unequal opportunities, such as access to higher education (Gildersleeve, Rumman, \& Mondragon, 2010).

Undocumented Latino students present unique challenges for school counselors and student affairs professionals. Cultural shifts, fears of deportation, and restricted opportunities for higher education and employment are common. Within academia, these barriers can be decreased when school counselors and student affairs professionals work collaboratively within a social justice model. The purpose of this article is to illuminate the challenges encountered by undocumented Latino students as well as introduce a social action model, based on Bronfenbrenner's ecological systems model (1998), which can be implemented within a K-16 setting. Collaborative social action interventions for undocumented Latino students using Bronfenbrenner's ecological framework will be included.

\section{Challenges and Barriers for Undocumented Students}

Depending on the age of the child, the migration transition can be a critical and traumatic experience (Perez, Espinoza, Ramos, Coronado, \& Cortes, 2009). Losing contact with friends and extended family can result in considerable grief. Further emotional issues can include: adjusting to an individualistic culture, learning the English language, living in crowded surroundings, and shifting role expectations within the family (Perez et al., 2009). In many states, undocumented Latino youth are unable to obtain a driver's license because they do not have government issued documentation or proof of residency, which can further complicate matters. Public transportation is often a guarded alternative due to cost constraints and an increase exposure to Immigration and Customs Enforcement (ICE) officials potentially leading to an increased risk of deportation. While legislative deliberation continues on the issues of immigration reform on federal and state levels, approximately 65,000 undocumented students graduate from high schools in the U.S. each year (Passel, 2006). Undocumented Latino students are graduating high school with little choice in what to do with the rest of their lives due to their lack of formal documentation. Given the disparity of a future, emotional and psychological hardships are common. 
Undocumented Latino students may also be going through developmental changes resulting in a time of increased isolation, confusion, and fear. Destructive stereotypes, hopelessness over one's future and unrelenting discrimination can also contribute to mental health and psychological problems among undocumented students. Historically, anti-immigrant rhetoric has led to "Hispanophobia", resulting in dehumanizing behaviors toward Hispanic immigrants (Jurado, 2008). Embedded within this stigma, conversations about immigrants explicitly suggest "otherness." According to the Southern Poverty Law Center (2011), the term "illegal immigration" implies the criminalization of individuals who are without legal documentation within the U.S.; however, unlawful presence in the U.S. is deemed a civil infraction, not a criminal offense. Stereotypical language and examples of media images often perpetuates continued stigma. Research by Perez et al. (2009) identified undocumented Latino students having "triple minority status," encompassing ethnicity, lack of American citizenship, and low socioeconomic status. These conditions have led to emotionally destructive labels and microaggressions that occur in and out of the classroom.

The results of the 1982 Plyler $v$. Doe court proceeding required public schools to provide an education for K-12 students residing in the U.S., regardless of their citizenship status (Shine \& Galisky, 2009). In spite of this progressive victory for school personnel and social advocates, the ruling fell short in providing undocumented Latino students an education beyond high school. As a college degree becomes an increasingly necessary commodity for competition within the workforce, undocumented Latino students are placed at a substantial disadvantage in comparison to their "documented" peers. It is the responsibility of professionals within the academic setting to advocate for social justice among all students within the K-16 system, including this marginalized population. According to the State Higher Education Executive Officers (2009): The terms "K-16" or "P-16" describes a movement by educators, political officials, and business leaders to work together in a more systemic way to strengthen educational achievement from pre-school through completion of the college degree.

\section{Social Action and Higher Education Change for Undocumented Latino Students}

Although steps have been taken to streamline education within the U.S., our lack of federal policy for undocumented high school graduates has been viewed as a civil rights issue (Perez, 2010a; Rincón 2008). Specifically, Rincón (2008) compares the lack of legislation for undocumented Latino students to the literacy tests and poll taxes against Chicanos and Blacks during the Jim Crowe law era. Immigration and Customs Enforcement (ICE) raids can also create controversy about one's civil right. ICE raids often place individuals in detention centers pending deportation and can greatly affect individuals, families, school districts, and entire communities (Shine \& Galisky, 2009). According to McCarthy (2009): "For many individuals coming to the United States in search of work, the potential economic benefits outweigh the significant risks of being caught, arrested, and deported" (p. 294). Yet, many undocumented Latino students live in fear of deportation (Contreras, 2009). Major crackdowns publicized by the media can influence an undocumented Latino's ability to meet even the demands of a daily routine. In May of 2008, an ICE raid in Postville, Iowa resulted in 389 arrests, devastating the entire community (McCarthy, 2009). Ultimately, McCarthy (2009) called for the need for the U.S. government to prioritize the human rights of individuals and the prevention of crackdowns such as the one which occurred in Postville. 
Recent legislation in states such as Arizona, Georgia, and Alabama has also stirred substantial civil rights controversy (CNN Wire Staff, 2010; Dwoskin, 2012; Valdes, 2011). Although Arizona's governor signed SB 1070 into law, providing law enforcement officials the jurisdiction to require proof of citizenship for anyone who looked suspicious, the federal Department of Justice issued an appeal stalling its implementation (CNN Wire Staff, 2010). In June 2012, the U.S. Supreme Court upheld the provision requiring immigration status checks during law enforcement stops. The civil rights concern surrounding Georgia's legislation also involves issues of racial profiling (Valdes, 2011). In times of economic crisis, stringent state legislation also has very real costs beyond the cost of individual human rights. Economists have predicted that Alabama's new anti-illegal immigrant legislation will cost the state $\$ 2.3$ billion and 70,000 jobs (Dwoskin, 2012). Education can provide an important first step in helping individuals understand the importance of civil rights.

Addressing cultural factors is necessary for system interventions to succeed and be effective (Hatzichristou, Lampropolou, \& Lykitsakou, 2006; Sue \& Constantine, 2005). Systemic change does not occur easily within an academic system. Adelman and Taylor (2007) identified the lack of nationwide training for school professionals on how to implement systemic change within schools. Furthermore, researchers have also found that sustaining long term change takes much preparation in the early stages (Schein, 1999), which may exhaust the patience and funding of school personnel at the high school and college level. Despite these struggles, many higher education institutions have made progress with systemic change based on enrollment rates of undocumented Latino students.

According to Redden (2009), approximately 54\% of four-year institutions and $70 \%$ of community colleges knowingly admit undocumented students. Less than half of all states have legislation permitting the enrollment of undocumented students. Some states have legislation allowing undocumented students to pay the in-state rate instead of the out-of-state rate (Gonzales, 2009). Conversely, a few states have passed legislation banning undocumented students from enrolling in state funded, four-year institutions and community colleges. As professionals in the field of academia, the time for systemic change has come. According to State Higher Education Executive Officers (2009), K-16 initiatives that include policies and activities aimed at early outreach, student preparation for college, and improvement of teacher quality can benefit all students, regardless of documentation status.

\section{Organizational Positions on Undocumented Students}

Professional organizations representing counselors and student affairs professionals have set precedents demonstrating social justice advocacy for undocumented Latino youth and their families. The American Counseling Association (2011) sponsored an educational session for its members at its national conference on the human rights issues surrounding undocumented individuals living in the U.S. (American Counseling Association [ACA], 2011). More recently, ACA (2012) and the Iowa School Counselors Association ([ISCA], 2011) have sponsored educational sessions at their annual conventions specifically on the challenges of career counseling with undocumented immigrant students. The American Psychological Association (APA) has come to a resolution and policy on immigrant children, youth and families. The organization recommends support and advocacy for the education and mental health care of undocumented individuals and encourages that detainees from ICE raids be held nearby to preserve the family unit (APA, 2011). 
College Student Educators International (ACPA), an organization committed to fostering college student learning, has advocated for the rights of undocumented students. Recently, ACPA supported the 2011 DREAM Act before the U.S. Senate Subcommittee on Immigration, Refugees, and Border Security (Roberts, 2011). Although precedents have been set on the significance of social justice advocacy, the American School Counseling Association (ASCA) has yet to publish a policy or position statement on working with undocumented students (ASCA, personal communication, February 28, 2012). The National Association for College Admissions Counseling (NACAC) has published recommendations along with facts and questions about how to best advise undocumented students (NACAC, 2012). The organization has also communicated that "professionals should work with undocumented students to the extent provided by state law" (NACAC, personal communication, April 14, 2012). Advocacy at state and national levels cannot be underestimated. The stance taken by these professional organizations continues to support the need for further social justice initiatives and advocacy on behalf of undocumented Latino students.

\section{Ethics}

Student affairs practitioners and school counselors may encounter ethical decision-making on a daily basis when working with undocumented Latino students, and a road map for how to guide such decisions can be found amidst federal legislation and student development literature. The Family Educational Rights and Privacy Act (FERPA) of 1974 protects the citizenship status of undocumented students (Gin, 2010). For this reason, school counselors and student affairs practitioners can keep citizenship status confidential in the same manner they maintain the confidentiality of other aspects of a student's record. Reynolds (2009) identified the most difficult ethical issues professionals encounter when working with students include those of confidentiality and competence. Understanding relevant institutional and professional ethical frameworks can help to guide the development of experience in decision-making. The ACA Code of Ethics (2005) encourages the use of ethical decision making models to assist counselors in carefully considering existing options with the decision making process. ASCA (2012) also provides ethical tips for school counselors to promote the best interest of student clients at all times. Additionally, Young's (2001) guide for making ethical decisions provides a step-by-step framework for school counselors and student affairs practitioners: be specific, reflect on the experience, involve others, understand basic ethical principles, try out alternative solutions, and reflect-in-action. While this model may not be feasible for every ethical decision made by a professional working with students, it provides a useful guide for how to handle decisions when working with undocumented Latino students and their families.

\section{Risk and Protective Factors for Undocumented Latino Students}

In a study conducted by Perez et al. (2009), undocumented students from high schools, community colleges, and four-year institutions across the nation participated to determine how risk factors, environmental factors, and personal protectors mediate student success outcomes. The researchers identified risk factors as working more than 20 hours per week, feeling a sense of rejection due to undocumented statues, having low levels of parental education, and a being a part of a large family. Environmental factors included whether parents valued the school, whether friends valued school, involvement in extracurricular activities and/or service, and involvement of both parents in a student's upbringing; personal protectors included 
participation in an honors program, valuing school, a high level of bilingualism, and distress regarding one's current situation. High-risk students with few protective factors did not fare as well as students who had high risk and more protective factors; measured outcomes included academic awards, overall GPA, and the number of advanced placement/honors classes taken in high school (Perez et al., 2009). This study suggests that protective factors are paramount for student success in lieu of environmental factors, especially since "educational opportunity such as college access is taught inequitably to undocumented students" (Gildersleeve \& Ranero, 2010, p. 21).

Undocumented Latino students have additional protective factors that enhance their resiliency to persevere despite risk factors. Many undocumented Latino students identify more with the culture in the U.S. than with the culture of their birthplace, which may facilitate adjustment to the predominant individualistic value system in the U.S. However, undocumented Latino students often originate from traditionally collectivistic cultures (Passel, 2006). Collectivistic cultures tend to place a high emphasis on the family system and actions are often taken in which the family will benefit, not necessarily the individual. Therefore if the family understands the long term familial benefit of obtaining a college education in the U.S., support from a collectivistic culture can be a strong protective factor for undocumented students. Students with supportive families may have higher retention rates during their academic journey. Rincón (2008) further identified undocumented Latino students who go to college are more likely to be involved in their community; participating in community service projects later in life, such as donating blood. Student affairs professionals and school counselors must consider how risk factors and protective factors uniquely color the experience of each individual undocumented Latino student. Considering the weight of these risk factors, these authors introduce a model for social justice advocacy in which student affairs practitioners and school counselors can work together to support undocumented Latino students.

\section{The Collaborative Social Justice Model (CSJM) for School Counselors and Student Affairs Professionals}

It is vital to examine where we currently function as an academic system when addressing the unique needs of undocumented Latino students. Using a framework in understanding the challenges and barriers of undocumented students, systemic intervention in the K-16 school system can be conceptualized by applying Bronfenbrenner's ecological and sociocultural model (1998). Bronfenbrenner's ecological systems theory examines development within a complex system of relationships that are affected by several levels of the surrounding environment (Tissington, 2008). Ecological frameworks have been useful in conceptualizing an understanding of a larger social ecology (Schriver, 2011), along with providing an understanding of sociocultural development within the context of subsystems. Within the academic setting, ecological systems theory highlights four nested structures (microsystem, mesosystem, exosystem and macrosystem) which have been applied to Latino student access to higher education in the past (Padilla, 2007) as a way to construct an understanding in how environmental influences can impact human development. Although a fifth system, the chronosystem, has been added to Bronfenbrenner's ecological systems theory (1998), these authors have chosen not to include this system as it focuses on the pattern of events that occur across the lifespan. Ecological models incorporate a framework for understanding how systems near and far from the individual have impact and influence on behavior and human development. We believe specifying this model for undocumented Latino students will allow professionals to assist in 
reducing the educational attainment gap for this unique population with continued marginalization.

In the quest for reducing this gap and advocating for social justice, these authors presented the CSJM at the Iowa Area Social Justice Meet-Up in 2011. The Meet-Up supported a variety of presentations and roundtable discussions enabling attendees to discuss topics of social justice, advocacy, resource and outreach, and best practices in working with students with various group membership. The event recruited professionals working in the fields of student affairs, mental health counseling, and social services throughout the state. The presentation included background and contextual information about the experiences of undocumented Latino students using Bronfenbrenner's ecological and sociocultural model (1998). Social action was taken by informing participants about the current state of immigration in Iowa and across the nation, in addition to providing resources and soliciting feedback on other ways advocacy can be taken. This experience provided the authors an opportunity to examine the relevance of the CSJM based on interactive discussions with professionals who work with undocumented Latino students.

In order to promote further social action on behalf of undocumented Latino students, the first author presented Undocumented Immigrant Youth: What Teachers \& Counselors Need to Know at the 2011 Diversity Conference to members of the Iowa education community. The main objective of the Diversity Conference is to promote and sustain diversity in education as well as provide tools to assist students in learning about diversity issues within the classroom (University of Iowa, 2011). Interactive methods were introduced and practiced to help future counselors and teachers learn how to best work with undocumented Latino students, both in and out of the classroom setting. Multicultural discussions and case scenarios were provided within the session to challenge the future generation of school professionals to embrace a holistic framework when working with undocumented Latino students.

As educators, mentors, and advisors, we must strive to make a difference in the lives of our nation's children, regardless of their documentation status. During this conference, the rising generation of soon to be teachers, student affairs professionals, and counselors were primarily Caucasian and from traditional Midwestern communities. The presenter provided contemporary information on the changing state of immigration, demographic and psychosocial issues of undocumented youth, the DREAM Act, and struggles of how professionals may help guide career development. The presenter discovered most participants had minimal understanding and experience in working with undocumented Latino students, and were interested and curious about providing the continued social justice advocacy on various levels.

Unlike resources in student affairs, there is a paucity of school counseling literature available on this topic to help guide school counselors in service delivery. Chen, Budianto, and Wong (2010) provided an excellent model in how to use group work as a method for social justice advocacy among undocumented immigrant students, but did not focus specifically on undocumented Latinos. These authors chose to center on the unique challenges of undocumented Latino students due to the high prevalence rates among all undocumented immigrant youth (Passel \& Cohn, 2008). The CSJM for school counselors and student affairs professionals continues to build on the sociocultural theory proposed by Gildersleeve and Ranero (2010) by addressing how systems impact undocumented students on a variety of different levels and within the context of the academic setting. School counselors and student affairs professionals, identified 
below as change agents, can embrace this model to enhance their knowledge, skills, and awareness while working with this population. Furthermore, the proposed collaborative interventions may enhance social action and advocacy that will benefit these students.

\section{The Microsystem: The Classroom Setting}

Practices by teachers, counselors and school personnel within the K-12 classroom may be of substantial impact to the undocumented Latino student. As noted by Sander, Sharkey, Olivarri, Tanigawa and Mauseth (2010), the relationship and daily contact between teacher and student is substantially meaningful and can directly influence student behavior. Assignments that enhance inclusiveness and understanding may prove to decrease bullying and microaggressions in schools. Classroom guidance lessons led by school counselors must be culturally sensitive and provide current information about prospects for future career options and barriers to accessing higher education. When possible, student affairs professionals should provide information to undocumented students directly, and discuss ways in which other undocumented students have been able to persevere in higher education. Additionally, assistance in securing financial resources, student engagement, and social/emotional supports are essential (Perez, 2010b). This is especially important given that undocumented students are less likely to use campus resources, such as a diversity office, than their documented counterparts (Contreras, 2009, p. 614).

\section{Recommended collaborative interventions}

1. Change agents can work collaboratively to strengthen the multicultural competency among teachers, administrators and school personnel.

Action Step: Develop and host multicultural trainings and workshops that educate school staff about the unique struggles of these students, including adaptations to different levels of acculturation.

Action Step: Provide information about undocumented students to school professionals via email, handouts, and presentations.

2. Teachers, school counselors, and student affairs professionals must have documents in the native language of the student's caretaker(s) to facilitate partnering with caretakers about the academic future of their children.

Action Step: Investigate translator services and online documents written in multiple languages that can enhance the multicultural sensitivity within the classroom setting.

Action Step: Seek out community members who are willing to be mentors to undocumented students. Mentoring from individuals who are of Latino background (community members, church members, current undocumented college students, etc.) may provide culturally responsive and sensitive insight to the challenges experienced by these students (Zalaquett \& Lopez, 2006). 
3. Change agents need to debunk the stigma of undocumented students and assist instructors in creating a culturally sensitive classroom by addressing the issues of micro-aggressions by peers.

Action Step: Work with teachers and instructors on anti-bullying campaigns and participate in anti-stigma groups can develop awareness among documented students, parents and other school personnel.

Action Step: Provide weekly support groups for undocumented Latino students and their families. Recruitment for these groups may be difficult to acquire depending on the school culture and openness of undocumented students and families. Active outreach to participants by school counselors, student affairs professionals and mentors is one avenue to approach this challenge. Individually addressing fears of deportation in a sensitive manner may need to be completed prior to group member recruitment.

4. Provide access to resources related to identifying pathways to citizenship.

Action Step: School counselors and student affairs professionals can provide materials regarding the process for attaining citizenship within the U.S.

Action Step: Collaborate with student legal services so undocumented Latino students have access to asking questions about pathways for citizenship.

\section{The Mesosystem: The Relationship Between and Among Change Agents}

Within the CSJM, the mesosytem includes inter-professional collaboration and enhanced connection with the families of undocumented students. K-12 school counselors and student affairs professionals need to develop relationships and establish connections that will enhance their visibility. Relationships between change agents may be limited due to different working hours and job responsibilities. However, taking the time to reach out between professions, instead of functioning in silos at separate institutions, promotes for the systemic change desperately needed for this population and is imperative to respond efficiently to student needs (Griffin \& Steen, 2011). Individual student planning may mean getting out of the office and joining with students and their families at a location, such as their home or religious establishment. Change agents need to explain to undocumented Latino families about their experiences working with undocumented students in the past to build rapport with families. They should also be aware that there may be an inherent imbalance in power between the helper and help seeker (Schein, 1999). Providing hope and collaboration may ensure greater opportunities in the academic future for these students.

\section{Recommended collaborative interventions}

1. Change agents need to understand and educate themselves about the cultural framework from which these students and their families emerged.

Action Step: Collectively address any issues of personal bias or stereotyping that they encounter with this group. Refer to resources on multicultural competence such as the Professional Competency Areas for Student Affairs Practitioners (ACPA \& Student Affairs 
Administrators in Higher Education [NASPA], 2010), the Association for Multicultural Counseling and Development's (AMCD) multicultural competencies (Arrendondo, Toporek, Brown, Jones, Lock, Sanchez, \& Stadler, 1996), the APA's guidelines on multicultural education (APA, 2003), social justice approaches to school counseling (Griffin \& Steen, 2011) and the Southern Poverty Law Center's Teaching Tolerance publication (available online). Change agents must demonstrate a respect for differences and carefully monitor their own biases.

Action Step: Model the levels of multicultural sensitivity to new school counselors, student affairs professionals, and interns. Cultural competency and advocacy must be infused on multiple levels (Griffin \& Steen, 2011), and modeling is one way in which change agents can take a leadership role when interacting with others.

2. Support the strengthening of relationships between undocumented Latino students and families with school personnel to establish trust.

Action Step: Facilitate office hours which will provide access to families of undocumented students. Stepping outside of traditional roles and office hours will help to build a trusting and therapeutic relationship between change agents and the undocumented student and family (Griffin \& Steen, 2011).

Action Step: Discuss and reflect cultural understanding of the expectations for undocumented Latino students by their families. The value of post-secondary education may be best communicated in the native language with this population.

\section{The Exosystem: Academic Policies within K-16 Institutions}

It is imperative for social justice advocates to remember that "the value that can be claimed in any given situation depends upon the institutional conditions, the formal status system, and the motives of the person within a particular role" (Schein, 1999, p. 110). Venturing farther out into the academic system may be an intimidating prospect for school counselors and student affairs professionals. Investigating the thoughts and opinions of the school board and questioning college admission practices must be done strategically and with an open mind. Recognizing that certain levels of the academic system may contribute to the problems undocumented students encounter may not be readily embraced by individuals working in schools and institutions of higher education. Certain policies may impede students' development; the common practice of requiring a social security number on institutional forms, for example, may result in students choosing not to participate.

\section{Recommended collaborative interventions}

1. Network and discuss the struggles of undocumented students with individuals responsible for developing and implementing academic policy.

Action Step: Advocate for undocumented students at this level by presenting information on the challenges and barriers of this population to school boards, deans, vice presidents, and other academic professionals. 
Action Step: Communicate transparently about the available scholarships, funding and resources for this population. School counselors and student affairs professionals need to be aware that academic policies in neighboring states may not reflect or resemble the current legislation within their residing state.

Action Step: Provide information on good practices when working with undocumented students and explore what other schools and colleges are doing in terms of social justice advocacy. Hosting a monthly or quarterly consortium with other school counselors and student affairs professionals dealing with transformative issues for undocumented Latino students, similar to an event held in Elgin, Illinois (M. Salgado, personal communication, April 4, 2012), is one way in which the sharing of resources can be established on a regional level.

Action Step: Advocate for the hiring of bilingual staff in order to meet the needs of students and families with English as their second language.

\section{The Macrosystem: The Cultural Values of K-16 Schools}

Due to the realistic barriers that undocumented students encounter, school counselors and student affairs professionals have an opportunity and responsibility to advocate for the social, emotional, academic and career development of these students. Students are often greatly influenced by their family members, peers, and school contacts, so the involvement of K-16 professionals is crucial. According to Oldfield (2007), undocumented immigrant students may not have the "cultural capital" developed by knowing someone who has navigated the educational pathways and could, therefore, have trouble transitioning to the educational system in the U.S. Research conducted by De Leon (2005) identified how relationships with teachers and school counselors facilitated optimism and perseverance among undocumented students, despite the vast barriers they encounter. School counseling and college student development approaches need modification to assist undocumented students.

\section{Recommended collaborative interventions}

1. Change agents need to guide the academic transition for undocumented immigrant youth due to this lack of "cultural capital" by taking on the role of mentor and advisor.

Action Step: Develop a formal or informal mentoring program that encompasses the worldview of the student.

Action Step: Collaborate with individuals working in secondary education and postsecondary institutions to enhance visibility, a necessity for beginning change within the K-16 system.

Action Step: Clarify the obstacles faced by these students with accreditors.

Action Step: Present at state and national conferences about the need for advocacy to work toward changing the cultural values within $\mathrm{K}-16$ systems. 
2. Change agents must advocate for federal and state immigration reform; without systemic change at a higher level, school systems do not have access to federal student aid or student employment opportunities.

Action Step: Promote and support opportunities for undocumented students by rallying and voting for social justice imperatives at the state and federal level (ex: DREAM Act).

Action Step: Discuss pathways for citizenship with legislators and become familiar with state policies that may limit access to undocumented Latino students.

\section{Limitations of the CSJM for School Counselors and Student Affairs Professionals}

While the CSJM seeks to address issues encountered by undocumented students at a variety of systemic levels, the authors recognize that the model has limitations. Financial access to higher education is a major barrier for undocumented students and cannot be resolved with this model. The Higher Education Act of 1965 (Title IV) prevents undocumented students from obtaining college financial aid, including resources such as student loans, grants, and work study programs (Gildersleeve et al., 2010). While school counselors and student affairs professionals do collaborate and few laws explicitly prevent undocumented students from attending colleges in the U.S., many students cannot enroll in institutions of higher education because of the inability to finance costs (Drachman, 2006). There are 12 states that have passed legislation providing undocumented students with the in-state tuition rate: California, Texas, New York, Utah, Washington, Oklahoma, Illinois, Kansas, New Mexico, Nebraska, Maryland, and Connecticut (National Conference of State Legislatures, 2011). After Texas passed in-state tuition legislation for undocumented students in 2001, Nores (2010) found that undocumented students were 1.5 times more likely to enroll in higher education. The authors encourage school counselors and student affairs professionals to identify the current legislative discussion surrounding access to in-state tuition in order to address individual college costs.

Paying for college can become increasingly challenging for undocumented Latino youth. They are unable to gain lawful employment in the U.S., preventing them from earning any income that could be placed toward college expenses. Hence, students may rely on their families to help with the cost of tuition, books, and other fees. Due to the low socioeconomic status prevalent among undocumented families, the majority of households do not have the resources to help students with financing the cost of higher education. School counselors and student affairs professionals must consider both cultural differences and individual differences when seeking to facilitate greater opportunities in higher education for undocumented students.

\section{Crafting a Readiness Environment}

Establishing an environment which is ready for change can also be a limitation of the CSJM. As noted by Adelman and Taylor (2007), systemic change within schools can be a difficult challenge and is often short lived due to a variety of factors. One key element is that change agents do not spend enough time creating an environment of readiness (Adelman \& Taylor, 2007; Schein, 1999). Major stakeholders, such as teachers, principals, parents, professors, admissions counselors and community members, must be educated on the true challenges that undocumented students encounter on a daily basis. School counselors and student affairs professionals have the ability to educate these stakeholders during parent teacher conferences, 
parent teacher association meetings, board and staff meetings, trustee meetings, as well as community engagements and events.

Weekend workshops dedicated to preparing parents, teachers, administrators, undocumented and documented students, and community stakeholders for system change could be collaboratively initiated to increase readiness. These authors recommend biannual or quarterly consortiums, such as the one most recently sponsored by Elgin Community College (M. Salgado, personal communication, April 11, 2012) titled: Psychological Impact of Being an Undocumented Student: Implications for Community College Counselors. Education about the obstacles that undocumented students encounter could be presented by school counselors, student affairs professionals, and undocumented students. Brainstorming sessions may include how to rally financial support for ACT/SAT testing, implementation of after school programs to assist students with increasing their GPA, and mass mailings (in native languages) about postsecondary institutions that openly accept undocumented students.

In addition to multicultural education and discussion, an environment of readiness also includes commitment, time, and institutional support (Adelman \& Taylor, 2007) from key stakeholders. Leadership changes among change agents may be necessary in order to provide an organizational environment that embraces advocacy for undocumented students to access higher education. Furthermore, school counselors and student affairs professionals (such as admissions counselors) may need to reach out to one another to further develop direct partnerships within communities.

An emphasis on enhancing home, school, and community partnerships must be the focus during the early stages of system intervention. As previously mentioned, school counselors and student affairs professionals may need to embrace non-traditional approaches such as meeting parents and community members at their homes. Schools and institutions of higher education need to open their doors to the community and provide an environment of openness to foster trust and support for social change. Holistic approaches may enhance culturally sensitive perceptions among parents, teachers, administrators and key stakeholders as well as create more "buy in" to aid undocumented students in their journey towards higher education.

Addressing cultural factors is also necessary for system interventions to succeed and be effective. Due to the stigma surrounding undocumented immigrants, it will be imperative for school counselors and student affairs professionals to assess how diversity impacts their schools and communities (Sue \& Constantine, 2005). This can be done via survey, interview, focus group and observation in multiple locations such as the high school, sporting events, community events and teacher's meetings. As noted by Sue and Constantine (2005), "organizations are microcosms of the wider society from which they originate" (p. 216). An accurate perspective of the differences between personal and systemic cultural sensitivity (specifically, schools and communities) will be crucial to move forward with systemic change to help undocumented students' access higher education.

It is imperative for change agents to remember that "the value that can be claimed in any given situation depends upon the institutional conditions, the formal status system, and the motives of the person within a particular role" (Schein, 1999, p. 110). In order to prevent relapse into non-culturally sensitive environments, school counselors and student affairs professionals must educate themselves on how to establish credibility among stakeholders, develop strengths 
based approaches and increase collaboration (Roosa, Dumka, Gonzales \& Knight, 2002). Addressing cultural perspectives within subsystems of the home, school, and community must be practical and gentle for sustaining systemic change.

\section{Conclusion}

As educators, mentors, and advisors, we must strive to make a difference in the lives of our nation's youth, regardless of their documentation status. School counselors and student affairs professionals have the opportunity to use the CSJM model as a holistic framework to advocate for undocumented Latino students. It is the professional responsibility and ethical duty for school counselors and student affairs professionals to work together to provide access to education for all those who seek it. This charge is perhaps best expressed by the illumination of the challenges encountered by undocumented students on an individual and collective level. Despite obstacles, undocumented Latino students can persevere and succeed in higher education. Future interventions for advocacy on behalf of this population will generate a student body that feels empowered and supported despite the challenges found while journeying through the education system in the U.S. That is, when academic professionals work together for social justice for all.

\section{Contact information:}

Cassandra A. Storlie

Counselor Education and Supervision

The University of Iowa

Email: cassandra-storlie@uiowa.edu

Elizabeth A. Jach

Higher Education and Student Affairs

Cornell College

Email: ejach@cornellcollege.edu

\section{References}

ACPA \& NASPA. (2010). Professional competency areas for student affairs practitioners. Retrieved from http://www2.myacpa.org/img/Professional_Competencies.pdf

Adelman, H. S., \& Taylor, L. (2007). Systemic change for school improvement. Journal of Educational and Psychological Consultation, 17, 55-77. doi:10.1207/s1532768Xjepc1701_3 
American Counseling Association. (2005). ACA code of ethics and standards of practice. Alexandria, VA: Author.

American Counseling Association. (2011, March). ACA human rights committee special symposium on counseling immigrants: Awareness and advocacy. Retrieved from http://www.counseling.org/Convention/PDF/2011-ProgramGuide.pdf

American Counseling Association. (2012, March). Challenges and strategies in career counseling undocumented immigrant youth. Retrieved from: http://www.counseling.org/Convention/.

American Psychological Association. (2003). Guidelines on multicultural education, training, research, practice, and organizational change for psychologists. American Psychologist, 58, 377-402. doi: 10.1037/0003-066X.58.5.377

American Psychological Association. (2011, June). APA resolution on immigrant children, youth, and families. Retrieved from http://www.apa.org/about/governance/council/policy/ immigrants.aspx

American School Counselors Association. (2012). Ethical tips for school counselors. Retrieved from http://schoolcounselor.org/content.asp?contentid=166

Arrendondo, P., Toporek, M. S., Brown, S., Jones, J., Locke, D. C., Sanchez, J. \& Stadler, H. (1996). Operationalization of the multicultural counseling competencies. AMCD: Alexandria, VA

Bronfenbrenner, U., \& Morris, P.A. (1998). The ecology of developmental processes. In W. Demon (Series Ed.) \& R.M. Lemer (Vol. Ed.), Handbook of Child Psychology: Vol.1 Theory (5 ${ }^{\text {th }}$ Ed.). New York: Wiley.

Chen, E. C., Budianto, L., \& Wong, K. (2010). Professional school counselors as social justice advocates for undocumented immigrant students in group work. Journal for Specialists in Group Work, 35, 255 - 261. doi:10.1080/01933922.2010.492897

CNN Wire Staff. (2010, July 28). Legal battle looms over Arizona immigration law. CNN U.S. Retrieved from http://articles.cnn.com/2010-07-28/us/arizona.immigration .law_1_arizona-immigration-law-illegal-immigrants-arizona-state?_s=PM:US

Contreras, F. (2009). Sin papeles y rompiendo barreras: Latino students and the challenges of persisting in college. Harvard Educational Review, 79(4),610-631. Retrieved from http://www.metapress.com/content/02671846902GL33W

De Leon, S. (2005). Assimilation and ambiguous experience of the resilient male Mexican immigrants that successfully navigate American higher education. Unpublished doctoral dissertation, University of Texas, Austin. Retrieved from http://www.lib.utexas.edu/ etd/d/2005/deleons30422/deleons30422.pdf 
Drachman, E. (2006). Access to higher education for undocumented students. Peace Review: $A$ Journal of Social Justice, 18, 91-100. doi: 10.1080/10402650500511667

Dwoskin, E. (2012, February 14). Alabama's immigration law could cost billions annually. Bloomberg BusinessWeek. Retrieved from http://www.businessweek.com/topnews/alabamas-immigration-law-could-cost-billions-annually-02142012.html

Gildersleeve, R. E., \& Ranero, J. J. (2010). Precollege contexts of undocumented students: Implications for student affairs professionals. New Directions for Student Services, 131, 19-33. doi: 10.1002/ss.365

Gildersleeve, R., Rumann, C., \& Mondragon, R. (2010). Serving undocumented students: Current law and policy. New Directions for Student Services, 131, 5-18. doi: $10.1002 / \mathrm{ss} .364$

Gin, K. (2010). Five secrets to success for undocumented students. Journal of College Admission, 206 (winter), 28. Retrieved from http://www.nacac.com/news_journal.html

Gonzales, R. (2009, April). Young lives on hold: The college dreams of undocumented students. Retrieved from http://professionals.collegeboard.com/profdownload/young-lives-onhold-college-board.pdf

Griffin, D., \& Steen, S. (2011). A social justice approach to school counseling. The Journal for Social Action in Counseling and Psychology, 3, 74-85.

Hatzichristou, C., Lampropoulou, A., \& Lykitsakou, K. (2006). Addressing cultural factors in development of system interventions. Journal of Applied School Psychology, 22, 103126. doi: $10.1300 / J 370 v 22 \mathrm{n} 02 \_06$

Iowa School Counselors Association. (2011, November). Career counseling with undocumented immigrant youth: Challenges and solutions. Retrieved from: http://www.iowaschoolcounselors.org/

Jurado, K. (2008). Alienated citizens: "Hispanophobia" and the Mexican immigrant body. Unpublished doctoral dissertation, University of Michigan, Ann Arbor. Retrieved from http://deepblue.lib.umich.edu/bitstream/2027.42/58455/1/kjurado_1.pdf

McCarthy, A. L. (2009). The May 12, 2008 Postville, Iowa immigration raid: A human rights perspective. Transnational Law \& Contemporary Problems, 19(1) 293-315. Retrieved from www.heinonline.org

National Association for College Admission Counseling. (2012). Undocumented students. Retrieved from http://www.nacacnet.org/searchcenter/Pages/Results.aspx?k =undocumented $\% 20$ students

National Conference of State Legislatures. (2011, October). Undocumented student tuition: State action. Retrieved from http://www.ncsl.org/issues-research/educ/undocumentedstudent-tuition-state-action.aspx 
Nores, M. (2010). Differences in college major choice by citizenship status. The ANNALS of the American Academy of Political and Social Science, 627, 125-141. doi: $10.1177 / 0002716209348748$

Oldfield, K. (2007). Humble and hopeful: Welcoming first generation poor and working class students to college. About College, 11 (6), 2-12. doi: 10.1002/abc.188

Oliverez, P. M., Chavez, M. L., Soriano, M., \& Tierney, W. G. (Eds.). (2006, May). The college \& financial aid guide for: AB540 undocumented immigrant students. Retrieved from: http://www.fao.ucla.edu/Forms/pdfs/07_08_ab540students.pdf

Padilla, R. (2007). Camino a la universidad/The road to college: A report to the Lumina Foundation. Retrieved from http://www.luminafoundation.org/newsroom/ topics.html?_stopic=0

Passel, J. (2006). The size and characteristics of the unauthorized migration population in the U.S.: Estimates based on the March 2005 current population survey. Washington, DC: Pew Hispanic Center.

Passel, J.S., \& Cohn, D. (2008). Trends in unauthorized immigration: Undocumented inflow now trails legal inflow. Washington, DC: Pew Hispanic Center.

Perez, W. (2010a, February 24). A new civil rights movement: Undocumented students for immigration reform. Huffington Post Los Angeles. Retrieved from http://www.huffingtonpost.com/will-perez-phd/a-new-civil-rightsmoveme_b_475479.html

Perez, W. (2010b). Higher education access for undocumented students: Recommendations for counseling professionals. Journal of College Admission, 206 (winter), 32-35. Retrieved from http://www.nacac.com/news_journal.html

Perez, W., Espinoza, R., Ramos, K., Coronado, H. M., \& Cortes, R. (2009). Academic resilience among undocumented Latino students. Hispanic Journal of Behavioral Sciences, 31(2), 149-181. doi:10.1177/0739986309333020

Redden, E. (2009). Data on the undocumented. Inside Higher Ed. Retrieved from http://www.insidehighered.com/news/2009/03/17/undocumented

Reynolds, A. L. (2009). Helping college students: Developing essential support skills for student affairs practice. San Francisco, CA: Jossey-Bass.

Rincón, A. (2008). Undocumented immigrants and higher education: Sí se puede. New York: LFB Scholarly Publications.

Roberts, G. (2011, June). DREAM Act testimony to Senator Dick Durbin. Retrieved from http://www2.myacpa.org/news-articles/dream-act-testimony-to-senator-durbin 
Roosa, M. W., Dumka, L. E., Gonzales, N. A., \& Knight, G. P. (2002). Cultural/ethnic issues and the prevention scientist in the 21st century. Prevention and Treatment, 5(5), 1-13. doi: $10.1037 / 1522-3736.5 .1 .55 a$

Sander, J. B., Sharkey, J. D., Olivarri, R., Tanigawa, D. A., \& Mauseth, T. (2010). A qualitative study of juvenile offenders, student engagement, and interpersonal relationships: Implications for research directions and preventionist approaches. Journal of Educational and Psychological Consultation, 20, 288-315. doi: 10.1080/10474412.2010.522878

Schein, E. H. (1999). Process consultation revisited: Building the helping relationship. Reading: Addison-Wesley.

Schriver, J.M. (2011). Human behavior and the social environment: Shifting paradigms in essential knowledge for social work practice ( $5^{\text {th }}$ Ed.). Boston: Allyn \& Bacon.

Shine, R. (Producer), \& Galisky, A. (Director). (2009). Papers/Papeles: Stories of undocumented youth [Motion picture]. United States: Graham Street Productions.

Southern Poverty Law Center. (2011). 10 myths about immigration. Teaching Tolerance, 39, 27-29. Retrieved from http://www.tolerance.org/magazine/number-39-spring-2011/10myths-about-immigration

State Higher Education Executive Officers. (2009). PK-16 systems. Retrieved from http://www.sheeo.org/k16/k16-home.htm

Sue, D. W., \& Constantine, M. G. (2005). Effective multicultural consultation and organizational development. In M. G. Constantine \& D. W. Sue (Eds.), Strategies for building multicultural competence in mental health and educational settings (pp. 212-226). New York: Wiley.

Tissington, L.D. (2008). A Bronfenbrenner ecological perspective on the transition to teaching for alternative certification. Journal of Instructional Psychology, 35 (1), 106-110. Retrieved from http://psycnet.apa.org/index.cfm?fa=search.displayRecord\&id=C4F01831-DCB5-AE5C7EFB-548946BE52EF\&resultID=2\&page $=1 \& d b T a b=a l l$

Valdes, G. (2011, May 13). Georgia governor signs controversial anti-illegal immigration law. CNN U.S. Retrieved from http://articles.cnn.com/20110513/us/georgia.immigration.law _1_illegal-immigration-immigration-status-law-enforcement-officers?_s=PM:US

Young. R. B. (2001). Ethics and professional practice. In R. B. Winston, D. G. Cramer, \& T. K. Miller (Eds.), The professional student affairs administrator: Educator, leader, and manager (pp. 153-178). New York: Brunner-Routledge.

Zalaquett, C., \& Lopez, A.D. (2006). Learning from the stories of successful undergraduate Latina/Latino students: The importance of mentoring. Mentoring \& Tutoring, 14 (3), 337353. 